\title{
Peace and the Formation of Political Order
}

\author{
Oliver P. Richmond ${ }^{1}$
}

\begin{abstract}
Contrary to most debates about state formation this article outlines an alternative perspective on the shaping of political community- and the international- based upon the agency of actors engaged in peaceful forms of politics after war. Drawing on long standing critical debates it investigates the positive potential of 'peace formation', outlining the theoretical development of this new concept as a parallel process and often in opposition to modern state formation with which it is often bound up in. It also examines the limits of peace formation and its engagement with old and new types of power and conflict. This perspective on the formation of political order has implications for the international peace architecture and its evolution, including in terms of a shift from analogue to digital forms of peace.
\end{abstract}

\section{"Context trumps everything"2}

“...Foucault created the twentieth century's most devastating critique of the free subject- and then... liquidated it.... Power was distributed, dynamic and nodal... Foucault's model of the

\footnotetext{
1 This article draws- and advances upon- on my book, Peace formation and political order in conflict-affected societies, OUP, 2016. Thanks to several reviewers for their very helpful comments. Oliver Richmond is a Research Professor in IR, Peace and Conflict Studies at Department of Politics, at the University of Manchester, UK. He is also International Professor, College of International Studies, Kyung Hee University, Korea and a Visiting Professor at the University of Tromso. His recent publications include Peace Formation and Political Order (Oxford University Press, 2016), Failed Statebuilding (Yale University Press, 2014) and A Very Short Introduction to Peace (Oxford University Press, 2014). He is editor of the Palgrave book series, Rethinking Peace and Conflict Studies, and co-editor of the Journal, Peacebuilding.

2 Pat Johnson, "Local vs National Peacebuilding: The Richness of Somali Peacemaking", (www.prio.no/peaceethics/PeacE-Discussions, June 2010).
} 
individual changed from 'determined' to 'partially self-constituting'... ${ }^{3}$

"Men make their own history, but not in circumstances of their choosing." 4

\section{Introduction}

Contrary to most debates about state formation theory and dynamics, ${ }^{5}$ this article outlines an alternative perspective on the shaping of political community based upon the agency of actors engaged in peaceful forms of politics, rather than war, violence, or extraction. It tries to extend the spirit and import of much of the critical work in peace and conflict studies over the years which is beginning to filter through into more mainstream thought and policy. ${ }^{6}$ It has endeavoured to move the debate from conflict management, to resolution, transformation, peacebuilding, onwards to the local level of agency, or to frameworks such as hybridity, scales such as the everyday, and related issues of resistance, identity, gender, and. ${ }^{7}$ This is a challenge

\footnotetext{
${ }^{3}$ For a brilliant analysis of Foucault's contribution to our understanding of the subject and power, see Eric Paras, Foucault 2.0, (New York: Other Press 2006), p. 158 p. 64, p.95.

4 Karl Marx, The Eighteenth Brumaire of Louis Bonaparte [1869], (New York: International Publishers 1969) p.15.

${ }^{5}$ Charles Tilly, "War Making and State Making as Organized Crime". In Peter Evans; Dietrich Rueschemeyer; Theda Skocpol. Bringing the State Back In. (Cambridge: Cambridge University Press 1985), pp. 169-191.

${ }^{6}$ Patrick M. Regan, "Bringing peace back in: Presidential address to the Peace Science Society", Conflict Management and Peace Science, 31 (4) (2013): 345 - 356: Paul F. Diehl, "Exploring Peace: Looking Beyond War and Negative Peace" International Studies Quarterly, 60 (1) (2016): 1-10

7 David Mitrany, A Working Peace System: An Argument for the Functional Development of International Organization. (Oxford: Oxford University Press 1944): J Galtung, J "Violence, Peace, and Peace Research" Journal of Peace Research, Volume: 6 issue: 3 (1969): 167-191; John Burton, Conflict and Communication: The Use of Controlled Communication in International Relations. (London: Macmillan and New York: Free Press 1969); John Paul Lederach, Building Peace: Sustainable Reconciliation in Divided Societies, (Washington, DC: U.S. Institute of Peace Press 1997); Roland Paris. At War's End: Building Peace After Civil Conflict (Cambridge: Cambridge University Press 2004); Oliver P Richmond, The Transformation of Peace, (London: Palgrave 2005); Oliver P Richmond A Post-Liberal Peace, (London: Routledge 2011); Vivienne Jabri. War and the transformation of global politics (Basingstoke: Palgrave Macmillan 2010); Karin Aggestam \& Annika Björkdahl (eds. Rethinking Peacebuilding: The Quest for Just Peace in the Middle East and the Western Balkans (London: Routledge 2012).
} 
to longstanding thinking about the nature of the state and international order ${ }^{8}$ in that it implies that peaceful political communities are formed through internal but networked and relational processes of legitimation, rather than state level or international process Yet, simultaneously, state and international level processes block or circumvent such "peace formation”.

Drawing on critical interests particularly in local agency, resistance and hybridity in IR and the more recent turns to local ownership, micro-politics, networks, and practice debates, as well as post-structuralist interests particularly in power formations this theoretical article investigates the positive potential and limits of 'peace formation', often along the lines suggested by concepts of social and global justice. It extends the arguments often made by those working in the areas of conflict transformation or peacebuilding into a newer, interdisciplinary and more comparative, trans-scalar and networked conceptual framework. It tends to be a bottom-up, intensely networked and mobile phenomena. The article places this new concept of peace formationdrawing on my earlier work- as parallel to, in opposition to, or alternatively formative of, a different type of state and international. It connects this alternative theory of order formation with critical debates surrounding IR theory, with implications for governance and the creation of stable and peaceful orders, as well as with a contrast between analogue and digital notions of peace and order. It does so through an eirenist and critical approach, ${ }^{9}$ which is also salutary in that its conclusions point to the significant limits of such locally and everyday oriented approaches to the development of post-conflict frameworks for political community.

In what follows I summarise the theoretical development of this new concept as a parallel process and often in opposition to modern state formation by asking a range basic questions about who carries out peace formation, how, and with what results, drawing on the empirical evidence I have amassed through recent research amongst several international institutions as well as in several

\footnotetext{
${ }^{8}$ Samuel Huntington, Political Order in Changing Societies, (New Haven and London, Yale University Press 1968).

${ }^{9}$ Oliver P Richmond, "Eirenism and a Post-Liberal Peace", Review of International Studies, Vol.35, No 3 (2009).
} 
peacebuilding and statebuilding spaces around the world. ${ }^{10}$

\section{The Paradox of Peace Formation}

Peace formation operates in local contexts, cultural, social, economic, and political spaces, and increasingly influences the state and international institutions. ${ }^{11}$ These 'local' processes provide contextual and social legitimacy, and cannot be imposed externally. ${ }^{12}$ They seek to determine the terms of emancipation for the community, polis, and eventually for the state. This has also historically given rise, via hegemonic states, to both regional and international organisation, and shaped international law and markets. Private transcripts inherent in peace formation are often networked and multiplied locally and transnationally, through civil society, customary governance and conflict resolution processes. They may arise in family networks, in professional or social networks, they may be hidden or public. In some cases, they move into the terrain of the state, shaping and modifying institutional processes, governance and law. They often become internationally connected, through INGOs, the UN system, donors, or family, social, cultural, or labour networks or other forms of association. These processes are often based upon pre-existing traditions, institutions, or norms that have often been targeted in wartime, but recover afterwards. They represent significant constituencies and a perspective that spans local, regional, and global historical, material, and social constraints and possibilities. Much of this operates within the older, analogue epistemologies of order, focusing on human interactions thought organisations and institutions, law, and association.

Peace formation provides a complex positionality through which to understand the realities

${ }^{10}$ Oliver P Richmond Failed Statebuilding, (Yale University Press 2014): Oliver P Richmond Peace Formation and Political Order, (Oxford: OUP 2016).

${ }^{11}$ This article and the concept of peace formation draws on my recent book, Peace Formation and Political Order, ibid.

${ }^{12}$ M. Foucault, "Two Lectures," in Colin Gordon, ed., Power/Knowledge: Selected Interviews, (New York: Pantheon, 1980): M. Foucault, Society Must Be Defended, (New York: Picador, 2003). 
of the multiple, ongoing attempts to rebuild peaceful social orders. There are two sides to this development. On the one hand, and from a small base, peace formation can be seen as examples of 'embedded, participatory, and communitarian' spaces in which local and international governance and assistance can converge sensitively, or they may be seen as creating spaces of parallelism, selfhelp and abandonment, where neither the state nor internationals care to tread. ${ }^{13}$

Thus, peace formation offers contextualised, networked agency in support of progressive forms of self-determination, political, social, economic, and cultural rights. It transcends the modern state framework, the norms of liberal peace, and the global political economy. It draws on already existing social capacity but it is also creative and innovative. Autonomy and human security, networks and associations, formal and informal, are vital for any peace. The more of them there are the better the mobilisation of local agency, and the more legitimate and the more stable the peace. In recent times, such agency has shifted into a 'digital' form, able to transcend the usual constraints of sovereignty (authority, territory, distance, power and knowledge constraints) through networks, mobility, access to enormous amounts of information upon which to make political calculations. Peace formation may indicate a capacity to bridge the old analogue international order with new digital forms of peace (also partly as a response to the ways in which new technologies have also become agents of violence).

These peace formation processes - an assemblage of local, state, transnational, international and transversal, formal and informal 'peace' processes with a heavy emphasis on the bottom-up perspective- constitute a widening pool of political subjects. They maintain a memory of historical peace practices and institutions related to custom, culture, identity, religion, or western norms of human rights and representation. They may seek to influence and hold government to account, seek international support to modernise and expand their practices, and set an example to wider society. They slowly insert contextual modes of politics into institution-building processes, legal and constitutional frameworks; and influence donors and other international actors. This implies that a

\footnotetext{
${ }^{13}$ Robin Luckham and Tom Kirk, "The Two Faces of Security in Hybrid Political Orders", Stability:
} International Journal of Stability and Development, Vol. 2, no. 2, (2013) pp.1-30. 
local-to-global coalition of actors is required so that a broader legitimacy can emerge. Yet local reconciliation and sustainability appears more feasible if legitimacy emanates from local agreements and processes (not only at the elite or national level). What is important is the way in which, in a minor register, peace formation agency tries to navigate, with varying degrees of success, around power and political deadlock, and whether international processes engage with and support it. It indicates how power is relational, and so can be rejected or modified even from a subaltern position. Peace formation thus endeavours to maintain everyday life where it can. Without it internationals distribute material and epistemic resources as a simulacra of peace or the state operates in an authoritarian mode. With it, the political order may become more representative and also receive guidance for its policies, practices, and institutions. Peace formation offers limited material support and sometimes goes as far as establishing parallel institutions that provide public services. Sometimes they managed to insert themselves into the state formation process, becoming a form of peace infrastructure. ${ }^{14}$

They have not only emerged from direct resistance, but a result of quiet perseverance in view of entrenched and dangerous power structures, drawing on critical social practices. It does so carefully because such 'peace work' entails costs, risks, and sanctions aimed at those who take part. This is because peace often threatens local ethno-nationalism, patriarchy, economic and political practices which maintain conflict, political authority, and forms of power. Every engagement peace formation dynamics and networks have with direct, structural, and governmental power inherent in conflict structures puts peace formation at risk of co-optation or complete negation.

Participatory and decentralised systems of democracy assume local agency should not be blocked. ${ }^{15}$ Peace formation agency is one of several foundations of a legitimate and emancipatory peace (along with the representative state, and the international system of law, norms, and institutions) that have emerged from history so far. It is aimed at mitigating direct, structural, and

\footnotetext{
${ }^{14}$ Andries OdenDaal, A Crucial Link: Local Peace Committees and National Peacebuilding, (Washington DC: USIP 2013).

${ }_{15}$ See for example Neil Harvey, The Chiapas Rebellion: The Struggle for Land and Democracy, (Duke University Press, 1998).
} 
governmental power in favour of the complex subaltern, deemed the font of legitimate political authority. It offers the pragmatic point that subjects of violence and power relations can identify these relations best, and probably spent a lot of time thinking about what to do about them.

The positionality of peace formation is complex, because it has to balance local legitimacy, identity, resource inequality, and historical positionality with modernisation and liberal theories backed by global institutions- expert knowledge in other words. ${ }^{16}$ It is scalar, networked and mobile rather than fixed in a territorial space. It is also pitted against the historical accumulation of power, and always operates in reaction to violence even though it remains permanently in the background working towards peace. Time and time again, peace actors and networks speak to these problems and have found ways of allowing such differences to co-exist in transformative ways, entwining them together: ethno-nationalism, pluralism, and liberalism in Cyprus, $\mathrm{BiH}$, or Kosovo; custom and indigeneity, self-determination, and the modern state in Timor, Colombia, or Afghanistan; and in all cases, religion, material needs, and the modern political economy; and yet more elements. Local agency sits agonistically between context and structure in a post-colonial world of hybridity. Thus, peace formation requires an 'ethics of the local': how conflict is caused, how it affects everyday life, how it may be dealt with in context in a positive manner, and how this is related to state and international order, increasing not just in analogue form, but also now networked, transversal and trans-scaler, and digital. This is may also require an ethics associated with new digital dynamics. It points to broad questions of justice, resource distribution, and the need for empathy and localised as well as transnational legitimacy. Peace formation may be the basis for legitimacy of any polity aimed at an emancipatory, and positive hybrid peace. It transcends power relations at the state level, and international frameworks for peace, but is also closely connected to both. ${ }^{17}$ It is the basis of concepts like bottom-up peacebuilding, peace infrastructures, and local agency for peace, and it should be closely connected to external processes such as conflict resolution, transformation, peacebuilding and statebuilding: indeed it should guide them, as it often has in the production of

16 Timothy Mitchell, Rule of Experts, (University of California Press, 2001).

17 Suthaharan Nadarajah and David Rampton, David, 'The limits of hybridity and the crisis of liberal peace', Review of International Studies, Vol. 41, No.1, (2015) 49-72. 
hybrid forms of political order. ${ }^{18}$

Within localised political, cultural, gender, identity, and socio-economic, stratifications, power structures are often based upon discrimination and inequality and their long-term maintenance. This means that any local peace is often negative, and relatively unstable. This also means that peace formation groups are often working against the majority in their own contexts, as well as not being fully in line with the goals and preferences of international donors, nor are able to move fully into the open because of security concerns. Both local and international actors, being increasingly aware of the hybridity of the peace framework that emerges from their mutual projects of peace, are also aware that this is a peace in negative hybrid form. ${ }^{19}$ Thus, in lieu of earlier theories of the social contract, legitimate authority, and state formation, peace formation foregrounds the question of what peace actors perceive as emancipatory, how they attempt to constitute an alternative order, as well the limitations on their capacity to do so. Peace formation is a rapidly evolving and very subtle phenomena, travelling along a path that might be familiar to scholars from post- or critical development studies, ${ }^{20}$ but also other, perhaps more liberal thinkers, such as Rawls, Habermas, and Nussbaum might recognise it. ${ }^{21}$ It raises a series of issues, some of which I discuss in what follows.

Who are the local agents of peace formation, what do they do, and what type of peace do they envision, with what implications for the international community?

\footnotetext{
${ }^{18}$ Volker Boege, Anne Brown, Kevin Clements, and Anna Nolan, "On hybrid political orders and emerging states: What is failing - states in the global south or research and politics in the west?" Berghof Handbook Dialogue Series, 8 (2008) pp.15-35.

${ }^{19}$ Oliver P Richmond, "Dilemmas of a Hybrid Peace: Negative or positive?", Cooperation and Conflict, Vol. 50, No.1, (2015).

${ }^{20}$ A Escobar, Territories of Difference: Place, Movements, Life, Redes (Duke University Press 2008).

21 John Rawls, "The Law of Peoples," Critical Inquiry, Vol. 20, No. 1 (1993) pp. 36-68: J Habermas. J The Postnational Constellation: Political Essays, (Cambridge: MIT Press 2001); Martha Nussbaum. Creating capabilities: the human development approach. (Cambridge, Massachusetts: The Belknap Press of Harvard University Press 2011).
} 
To understand the local agents of peace formation and their role, we have to comprehend subaltern power, the importance of the local scale in terms of knowledge and legitimacy, their transversal and transnational networks and mobility, but also the marginal nature of peace formers in relation to existing international and local power structures. So local authorities, peace networks, and advocates of reform situated in the cultural and material context of a specific context provide crucial signals as to how peace and order can be reconstructed. Yet, quite often their messages challenge existing power structures such as elites, the state, and internationals, and take a long time to percolate through. Peace formationarises nearly always after the event of war, and yet is an intergenerational background phenomena. Peace formation dynamics and actors offer a cultural and ethical site of knowledge about peace and order, which may be translated through tactical and critical agency into political reform. Local or 'organic' intellectuals, activists and advocates, some policymakers, politicians, and bureaucrats, some professionals, social, cultural, religious, identity, labour, and leisure networks for everyday associations that provide a three dimensional vision of peace and order. Often this is deterritorialised, transnational, and transversal, aimed at an emancipatory and empathetic form of peace. Historically such networks, movements, and everyday forms of mobilisation drive towards this. Peace formation offers a historical and social positionality necessary for local scale legitimacy. It increases in scale over time after violence stops, and as networks and institutions are built—but peace formers also want autonomy, introducing a dangerous contradiction into the equation between peace and power. Peace formation spans politics, economics, culture, and identity into emotional and creative areas, bridging difference, where power structures, social, political, economic, cultural and territorial systems accentuate difference as a zero-sum process or at best an ugly hierarchy (or 'balance'). It is connected to emerging non-Eurocentric thought on global justice (in environmental, security, gender, historical, and distributive forms, among others). Peace formation's new digital capacity expands the rights claims it can make, disguises it, speeds it up, extends its reach, although it also now confronts the forms of violence new technologies produce. 
Are these often marginal peace formation dynamics able to mitigate the violence of local state formation?

Conflict, war, and other forms of violence, are mitigated by social, legal, and political institutions and mechanisms in society. However, peace formation is seriously disrupted by violence, and though it works in the long-term and in the background, it also requires time to reconstitute after violence. Furthermore, it is often aimed at combating the 'last war' rather than the next. However, it leads to the possibility that a networked polity, with internal power, exists in society before (or in spite of) the state, which is aimed at maintaining order and responds to expectations for progressive reform, albeit in limited ways. ${ }^{22}$ This partly represents what may be called the 'undercommons' of peace formation (hidden away from the worst excesses of violence, but also spanning a much longer time frame), aimed in part at dealing with local power structures, as well as the newer exclusions that are arising from the contemporary neoliberal global order. ${ }^{23}$ In this way peace formation has something in common with new social movement theories. Social actors negotiate their own peace drawing on long-standing, quiet forms of legitimacy and legitimate authority, display some albeit limited agency, even over direct and structural power, and certainly against governmental power. In most cases, such organisations use external concepts such as development, human rights, human security, and democracy upon which to pin their claims. Often less visible is their valourisation of mediated identity, and their critiques of the inequities of the international system, both past (colonialism) and present (neoliberalism and euro-centricism).

Indeed, peace formation is one of the multiple and entwined historical roots of the state, albeit rarely recognised by elites or internationals, who focus on power and its more negative foundations. Its role has been to balance the state's excesses of power and maintain an

\footnotetext{
${ }^{22}$ See for example, a similar argument about the EU in Ulrich Beck and Edgar Grande, Cosmopolitan Europe, (Cambridge: Polity, 2007).

${ }^{23}$ Max Haiven and Alex Khasnabish, The Radical Imagination, (London: Zed Books, 2014). p.12 \& p.44.
} 
emancipatory project both through and despite the state. ${ }^{24}$ Peace formation's aim is to expand the possibilities for peaceful everyday life requiring both transformation and cooperation, and a retreat from a methodological exclusion often embedded in practices of power and intervention. Context empowers such agency, even if it cannot countermand structural, direct, or governmental power. Its digital extension provides the knowledge required to extend such claims in a much broader context too.

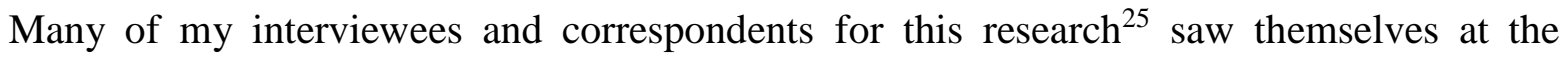
vanguard of international progress and reform, as well as within their own state and community, despite their apparent marginality to state and international political and economic power. They recognised the roles of the UN, EU, World Bank, or INGOs, but also saw them as dependent on increasingly outmoded approaches and norms, and subject to hegemonic or dominant state interests. ${ }^{26}$ Peace formers often felt they were working for themselves and their own, local but also often networked, trans-national and/ or transversal communities, in ways that they had defined, and were confident of a slow and hidden multiplier effect emanating from their efforts. ${ }^{27}$ They also formed networks of their own, sometimes whilst also formally working for international organisation or NGOs.

Across large parts of the developing and conflict-affected world, it is a normal part of life for citizens to operate in different modes of politics, informal and formal institutions, law, and identity, simultaneously. What has also become clear is that locally sited systems of legitimate authority need to be mirrored by the state if any peace system constructed around statehood is also to have internal and international legitimacy. This raises some obvious issues, already noted across the literature, including the self-defeating nature of territorialism, the prioritisation of elections

${ }^{24}$ Arjun Chowdhury and Raymond Duvall, "Sovereignty and Sovereign Power", International Theory, Vol. 6, No. 2, (2014) p.218.

${ }^{25}$ Oliver P Richmond, Failed Statebuilding, Op. Cit: Oliver P Richmond, Peace Formation and Political Order, Op. Cit.

26 This was a view I heard at NGOs and social organisations, repeatedly, in Kosovo, Bosnia, Colombia, Sri Lanka and Cyprus.

27 For example, the staff at Balkan Sunflowers mentioned this explicitly. Focus Group, Balkan Sunflowers, Pristina, 23 May, 2014. 
(though democratisation is a demand emerging broadly from peace formation), and a need to invest in public services in a comprehensive fashion, particularly in education, health, and income support. Inequalities, often the basis of conflict- cannot be dealt with without an active state, supported by international donors, in such areas. Nevertheless, this means cutting across local power structures as well as having a strong international consensus, both of which are difficult and fleeting.

This means that peace formation is a slow process (in analogue terms at least), which builds upon a number of different and sometimes contradictory systems: the move towards regional integration and international law, and global governance (i.e. the liberal international order) is certainly one key aspect, in a formative international community. The reform of the state away from its earlier clash of power and interests into a more social form is another key aspect. But there is also an underground dimension which signifies a different type of political community, which both more autonomous but yet is far more relational, across time and space, and may not be solely directed towards state reform or international links (especially in the newer digital format). Peace formation seems to be a slow and quiet process of reform, reconciliation, respect, and institutional development, rather than a revolutionary process of state or international re-structuring. It also appears to be discordant with modern state and international processes, at least superficially, raising concerns that any engagement with peace formation will constitute neo-colonialism. This is a paradox relating the problem of how subaltern claims become politically salient in relation to existing power structures, without being co-opted. Both are inevitably mediated, but co-optation is unlikely given these are peace formation rather than state formation forces (ie driven by principles rather than material aims). This process is far from a simple dynamic of domination and submission.

In this way, at times peace formation may be open to the criticism that it maintains or merely tweaks a painful and unjust status quo (as in $\mathrm{BiH}$ or Israel/ Palestine), or is eventually coopted into the formal power structures of the state without significantly changing them (as in the case of many peace infrastructures), or leads to isolation (as with the inter-communal groups in Cyprus), or a dangerous parallelism in political order, which threatens the stability of the state if it 
does not reform to incorporate them (as in Timor Leste). At the same time, it is clear that in every one of these examples, the constituent actors and networks in the peace formation process resolve issues and make some political space for discussions about the nature of peace. In everyday terms, one might say that for as long as they survive, a successful peace process already exists.

Nevertheless, one major problem with peace formation is how easily extinguishable it is, or how easily it may drop from view. These dynamics- disappearing to escape sanction and being disrupted or ended by conflict actors- are where the praxis of intervention for humanitarians, development specialists, the various programmers of liberal peacebuilding, and in some cases, peacekeeping forces, might be reframed.

Peace formation may be stifled by clientelism and neopatrimonialism, which is not in favour of reform. In some cases, however, it appears that peace formation actors are able to mitigate such dynamics even with minimal resources. They may do so within the very same normative or social network that clientalism uses. Dependent upon a deep understanding of local politics, this highlights the need to let local actors take the lead in discursive terms, even if the power required to stop war and make space for diplomacy, mediation, negotiation, and reconciliation (intervention in other words) must come from outside of the conflict-affected areas. Its digital framing collapses the concept of outside/ inside to a degree, offering a new perspective of how peace accepts cooperate across different scales.

What are the subaltern critiques of developmental, liberal peacebuilding or statebuilding projects, and how do they respond to their encounter with local actors?

Peace formation points not just to the need to deal with security, rights, and a viable state, but also local historical constructions of identity and authority, and international inequality. Justice at local and international levels in general terms is highlighted by a peace formation positionality. Yet, it 
also points to the limits of liberal global justice accounts ${ }^{28}$ and the insertion of alternative traditions. Neoliberalism is widely critiqued by peace formation actors, who argue that it creates significant tensions in a peace process where political and human rights, and justice, are deemed to be key to addressing the roots of a conflict and to building viable and legitimate institutions. Furthermore, any peace process creates new demands for a wider social justice, because of the legitimacy of the agency of local actors, even if long latent.

The peace dividend is found in the recommencement and mutual negotiation of improvements in patterns of everyday life disrupted by the conflict. While peace formation offers a progressive rethinking of peace, rights, class, gender, and resource distribution, the state often is controlled by elites who block progress, indirectly utilising the resources that internationals provide them with. From this arises resistance towards pathway dependency, one size fits all blueprints, standard operating procedures, and post-colonial and anti-colonial narratives about intervention. From here also arises the tendency of peace formation to adopt a parallel track, which challenges the state's claims to have become domesticate and oriented towards the interests, rights, and needs of citizens. Parallel track peace formation may also be forced underground in order to survive state or elite repression, to recuperate enough capacity and develop (analogue and digital) tactics aimed at reshaping the state through localised strategies or international alliances.

Do peace formation actors modify the liberal and why? Or do they follow their own peace agendas? Does this lead to a clear alternative or a liberal-local hybrid version?

Peace formation implies a post-colonial version of peacebuilding and statebuilding, which means that its current economic and normative underpinnings need to be expanded, as does their conception of the relationship between society and legitimacy. Peace formation implies concern

${ }^{28}$ Richard Shapcott "Global Justice: Shaped rather than Found", International Relations, firstview (2017) 2. 
about inequality in material, gender, and identity terms, as well as with solidarity and empathy. The bottom-up drives the formation of legitimate authority if it emerges from peace formation, which will be hybridised and relational, depending upon complex transversal and transnational networks. The subaltern power exercised by peace formation makes the replacement of the direct, structural or governmental power of powerful elites or international actors unlikely. The dynamics of insurgency, critical agency and the subaltern, resistance, and alterity, point to the doggedness of 'resistant subjectivities' and 'subjugated knowledges', and their focus on peace in everyday life. They all make emancipatory claims, but at best all the examples in existence- Timor Leste, Cyprus, Kosovo, Bosnia, Sierra Leone, Afghanistan, and others- point to the emergence of a negative, hybrid form of peace.

Hybrid political orders are a more significant sign of the capacity of peace formation processes and actors to nudge or reshape power structures, either at the elite level or those associated with liberal peacebuilding. What tends to arise is a blend of different forms of political authority, connecting peace formation to existing elite power-structures, civil society, the state, the international peace architecture, as well as the global economy. A new struggle for dominance of political order in these terms emerges, and in recent times has been dominated by an alliance between capital and elite power, with peace formation operating from a parallel track, which nevertheless impinges upon the evolution of the state (as might be clearly seen in cases like Timor Leste, Cambodia, or Kosovo in very different ways). A key question for the future will be to engage with the problem of whether the relatively easy shift into a digital terrain for such agency will undermine its capacity to deal with more analogue forms of state or global power, but the expectation and the evidence so far points to how peace formation both modifies hegemonic systems and develops its own peace discourses.

How successful have peace formation strategies been?

Four main possibilities emerge from this study for peace formation dynamics. 
i) They survive in the informal shadows, away from the risks of crossing powerful actors (as in Kosovo before 1999 where services and self-determination circulated away from the gaze of formal authorities) and avoid the risks of moving into public space.

ii) They move in the public space, and take this risk (as in Cyprus where the intercommunal movement stepped out of the shadows with international support in the early 2000s) but they also adopt the liberal peace/ neoliberal state international architecture and accept their (lowly) place in the current international hierarchy and system but without any right or capacity to change it (as perhaps also in Kosovo, Bosnia or Colombia).

iii) They may try to choose only the positive aspects of the liberal peace system and discard the rest (though there are no real examples of this).

iv) They may build a hybrid system, in which they have some greater stake in the whole, while also recognising power relations (as in Timor Leste, Somalia, Somaliland, and others).

These different dynamics indicate that peace formation plays a role in building order, different in every case. This is success of sorts.

Peace formation uncovers conflict-sustaining inequality, and at least in discursive terms indicates the existence of a small but growing network of plural and micro solidarities: it highlights relationality, bridging and translation claims for pluriversality, equaliberty, heterotopias, transscalarity, and transculturalism. It rescues such dynamics from the past, or manufactures them for the future, focusing on their transnational, cultural, and social legitimacy. For many reasons, on paper a positive hybrid peace may thus be imagined. 
Contextual knowledge is of great tactical value in maintaining peace formation against local and state level conflict, and against inappropriate international blueprints or involvement. It has little capacity against direct violence or war, but it provides pathways through insecurity. It also provides some defence against unrepresentative global governance, though it has little capacity against predatory aspects of global capitalism. Clearly, any legitimate peace and order is unsustainable without the support of subaltern or critical agency and society in general (other than through structural, or perhaps governmental power). Peace formation provides a social form of governance, often without formal government. The peace and state that emerges from this process is likely to be contingent, fragmented, decentralised, and capable of supporting peaceful alterity ${ }^{29}$ discursively, if not in practice. Though it cannot respond to direct, structural or governmental forms of violence, it can work on their delegitimisation, digital methods appearing very effective here. It also connects with the emancipatory wing of liberal thought, hybrid notions of law and transitional justice, participatory democracy, human rights, context and dignity, poverty, lack of resources and facilities, and inequality. Concepts such as local ownership, participation, Responsibility to Protect, sustainability and 'do no harm', have emerged because of it, pointing to more critical, post-colonial or anti-colonial dimensions. Hybrid approaches to decentralised governance and law, involving local leaders and processes, have also been recognised as important because of it. Expanding rights claims have cascaded from the local scale upwards as a result.

Peace formation and its informal critical agencies as well as its collective political mobilisation dynamics from within civil society may do little more than mitigate everyday life in material terms, but in the longer term it may be able to move into the open and begin to connect with and shape the state as well as influence donor strategy. It may develop informal governance without a state, following transcalar and transversal networks.

Four key strategies emerge from this analysis. This confluence may start with parallelism

${ }^{29}$ Roland Axtmann, “The State of the State”, International Political Science Review, Vol. 25, No. 3 , (2004) p.259. 
(as in Afghanistan, Palestine where peace formation is forced to work under cover, and in parallel to existing and new power structures relating to the conflict and the state entities). It may involve bridging (as in Timor where peace formation processes helped translate local forms of legitimate authority and make the state more legible to them). It might involve co-opting (as in Bosnia where is seems that peace formation processes are partly controlled by state formation actors). It could lead to a take-over (as in Kosovo where peace formation actors and state formation actors took control of the state to a large degree). It may influence civil society, the state, or donor strategies. It may be deemed successful if the resultant state- or system of governance is more representative, allows for the expansion of rights and justice, donor strategies are more sensitised, and local ownership and autonomy has been upheld, along with democracy. Success may well depend on the way informal processes maintain and improve everyday life, and more ambitiously, form networks that begin to find support within the international community and more formally begin to reshape the state, social norms, as well as donor policy. ${ }^{30}$ It may also point to the emergence of scale jumping where positionalities are altered beyond the canon that can be easily recognised in formal liberal political philosophy. ${ }^{31}$ This might seem to overload the potential of peace formation, but it is also in line with the autonomy that is often claimed by its proponents.

\section{Methodology and Peaceful Order}

Peace formation indicates that 'expert knowledge' is subjective and often hegemonic and not well suited to meeting claims made at the local level. Likewise, peace formation is limited in terms of scope and power by the very power structures it opposes and by its networked and mobile rather than concentrated nature. A multidimensional methodology and interdisciplinary approach is needed

\footnotetext{
${ }^{30}$ Andries OdenDaal, Op. Cit., p.23.

${ }^{31}$ J Agnew. Place and politics. (London: Allen and Unwin 1987)
} 
to understand these dynamics, blending social theory, philosophy, anthropology, geography, as well as IR and political science. This methodology may also be translated into law and economics at a later moment of consolidation. Peace formation requires a research methodology suited to engaging with local, informal, knowledge and creating equal partnerships, decentralised power and redistributed resources. To avoid recreating trusteeship and native administration bureaucracies, it needs to be linked to political self-determination and autonomy and through awareness of inequalities relating to post-colonial and gendered analyses, avoid the risk of inadvertently supporting unjust outcomes or processes. The subtleties of peace formation point to how deconstruction assists in the emergence of justice. Subjects have, over the last 25 years, uncovered the very power-systems which drive conflict as well as how they are perpetuated through intervention (often inadvertently), and now point to how reconstruction may attain justice. ${ }^{32}$ As Foucault argued, peace formation, self-formation, and local knowledges are in a constant struggle for survival against industrialised knowledge and disciplinary power- states, the international architecture, and the global economy. ${ }^{33}$ Peace formation requires the recovery and assertion of subjugated knowledge. Furthermore, its digital shift to some degree undermines inside/ outside, topdown/ bottom-up frameworks: it collapses space, speeds up interaction, extends networks, supports the knowledge side of the power-knowledge equation, and offers camouflage in situations of danger. This reframes agency as far more relational than hitherto understood, ${ }^{34}$ and this has significant impact on the micro construction of political order and legitimate authority, whether local, state, or global. ${ }^{35} \mathrm{New}$ methods are required to engage with these dynamics.

\footnotetext{
${ }^{32} \mathrm{~J}$ Derrida, Force of Law, in D Cornell et all (eds.), Deconstruction and the Possibility of Justice, (London: Routledge, 1992) p.15.

${ }^{33}$ Michel Foucault, Society Must be Defended, (New York: Picador, 2001), p.179.

${ }^{34}$ Yaqing Qin. “A Relational Theory of World Politics". International Studies Review Volume 18, Issue 1, 1 March (2016) 33-47

${ }^{35}$ Ty Solomon \& Brent J. Steele "Micro-moves in International Relations theory", European Journal of International Relations, Vol 23, Issue 2( 2017): 267 - 291
} 


\section{Some Important Caveats}

This argument does not constitute a claim that all that is local, networked, and politicised agency is potentially emancipatory. Indeed, peace formation agency is often in a very minor scale. Local actors, communities, and networks are subject to often grotesque power-relations, around which peace and politics revolve. These power relations are often directly supported by external actors' contacts with military, political, and economic elites, the role of security, economic, political and other advisors, programmers, and consultants. Global capital also tends to play into the hands of such powerful networks. Peace formation actors are often far outweighed by local nationalists, sectarians, conservatives, or other groups who oppose reconciliation and compromise, and may even support the use of violence. Nevertheless, this means it is also all the more fascinating that peace actors continue to emerge with clear views on emancipation, peace, the state or form of polity, and international support.

Much of the empirical evidence on peace formation is anecdotal, or scattered and impressionistic, partly because of the well-known risks activists and social movements take in responding to entrenched power-relations or practices. Any reconstruction of a historical political record, at whichever level, will probably be susceptible to such weaknesses, however. So far a fragmented record and some affiliated theorisation has only just been brought into view. It might be said that in a range of literature spanning Marx to Foucault, the sense of political agency has been theorised more strongly than it has been practiced (or at least empirically researched). Nevertheless, subaltern agency is not much of a match for governmental, structural or direct power. Some peace processes only exist (in terms of reconciliation and emancipation) at this level, as the state, regional, or international levels have long been deadlocked (as in the Middle East, Bosnia and Cyprus, as well as others). Peace formation's discursive signalling represents a positionality from which local to global dimensions of a peace process and settlement can be viewed and tested. Nevertheless, this is a highly politicised process: it is predicated upon a struggle for rights and material needs often against entrenched power structures, vested interests, and received wisdom amongst outside 
experts.

\section{Theoretical Reopenings: Convergence versus Ungovernmentality}

Historically, political order has always been shaped by the paradox that the institutional mechanisms of war and militarism do not develop at the same pace as the mechanisms related to peace formation. The evidence tends to show that peace formation systems may collapse under acute direct and structural pressure from external forces but they always find ways of adapting and re-establishing themselves in order to counteract violence, digital shifts being a recent adaptation. This is a slow, long-term process, in which peace formers are vulnerable, but they establish private or public, informal, or governmental associations and networks. These slowly offer a platform for reform aimed at more progressive politics, drawing on traditional associations, networks, and history as well as international norms. Peace formation is vital in preventing state reform and any peace process from simply consolidating the political order created by conflict. Thus, peace formation may lead to a social convergence with governance and international norms and one end of the peacebuilding scale, as might be said in the cases of Timor, Kosovo, or Cyprus. At the other end of the scale, and inevitably where resistance to negative peace emerges from within society, peace formation produces the paradox of resistant and critical agency. In its opposition to the governmentality from previous exercises of direct or structural power that attempts to normalise injustice and oppression (as might be seen in Palestine or Colombia) subaltern agency, discursive critique, dissent and resistance (whilst avoiding violence) produces 'ungovernmentality'. That is, networks and groups opposing forms of quasi-peace associated with a naturalised consolidation of hierarchy and injustice, and which are discursively engaged in imagining a just form of peace.

Peace formation from below continues during the conflict and long afterwards. As in Cyprus and Colombia, for example, whenever the formal, high level peace process stumbles, or the state that comes into being proves unable to deal with the diverse claims that arise from society (for 
example, when pluralism and nationalism are in tension, when rational-legal institutions are unable to provide security, law, or order, or when neoliberalism undermines solidarity), peace formation begins to fill the gap. It may reshape the state, or it may provide a basis for everyday life to continue despite state-failure or injustice. Individuals and groups within society in many different locations around the world engaged with peace movements and processes often describe how they are slowly and incrementally piecing together a new peace, often drawing on existing agency and previous social institutions or practices as well as international norms, combined with their own innovative thinking. Often they are searching for a new and alternative vocabulary also.

This has often happened without much or any outside help, and in the face of considerable structural and direct violence. The slow and painful piecing together of new services, institutions, and agreements on how to distribute resources or bridge identity difference, and offering assistance to those who need help, is a marked characteristic of every post-conflict society. In Cyprus people have organised inter-communal events and projects despite massive resistance and suspicion from both sides of the buffer zone. In Colombia people attend civil society meetings to share their experiences, network, and ask for advice, as well as state their principles, and assert their needs, even though their communities were often under fire, under curfew, or they face historical systems of oppression (not least the impact of global or elite capital). In $\mathrm{BiH}$, organisations continue to struggle onwards for human rights, to assist in peace education, to lobby politicians and internationals, even forming plenums within which to publically debate and mobilise. In Somalia and Somaliland, customary governance compensates for a lack of viable state or international support. In Timor and others, hybrid forms of state and governance emerge to keep the peace, build a better future, and to maintain the support of a range of local to global scale parties. ${ }^{36}$ In all cases, such activity was despite (though very aware of) the risks of opposing mainstream politics, economic arrangements or social customs. The agency that is displayed and the way the visions developed transcend conflict is impressive, creative, and astute, but all too often blocked by elites focused on their interests and internationals focused on their own models.

\footnotetext{
${ }^{36}$ Oliver P Richmond, Peace Formation and Political Order, Op. Cit.
} 
Ungovernmentality, then, is a sign that innovation in the production of a peaceful political order is taking place, which identifies the dynamics of conflict, resists their perpetuation, refuses to deploy violence, forms trans-scalar and trans-temporal networks and associations, and subtly works to displace naturalised orders that entail governmental, structural, or direct forms of violence with more progressive and legitimate forms of political order. Convergence between local, state, and international scales, might be the result (as the cases of Kosovo or Cyprus may eventually illustrate), as with some versions of peace infrastructures, but it is also possible that difference requires mediated autonomy between these scales, as with Somaliland or Timor). 'Grounded legitimacy' is essential for the broader production of hybrid legitimacy, ${ }^{37}$ itself a product of local, state and international frameworks and the tensions within and between them. ${ }^{38}$

In practice, this is a painful process in which actors across society identify problems that are and have been causal factors in violence in historical, social, political, economic and identity terms, and begin to act. Their first act often takes place in a hidden manner, perhaps resisting or co-opting. When they are more assured they begin to form networks, perhaps underground, normally informal, but often engaging with international donors and moving into local, national, and global public spaces if possible. They begin to informally network with local power elites, and perhaps even the state. Eventually they acquire a name, funding, status, and even begin to advise or occupy the state and international networks and roles. It is a slow process almost in 'geological time'. It represents the slow reforming of solidarity in society, a realisation of agency, and a development of strategies to stop violence as well as to deal with the consequence of violence. Subaltern agency is wielded, and faint signals are offered about the nature of an emancipatory peace, how the state should be reformed, and how the international might assist or enable. The recent digital shift has strengthened these faint signals, however.

\footnotetext{
${ }^{37}$ Volker Boege et al, Op. Cit, pp.5-35.

38 Volker Boege, "Legitimacy in hybrid political orders - an underestimated dimension of peacebuilding and state formation". Conference paper presented at the European Consortium of Political Research conference, Potsdam, Germany, (10 -12 September 2009): Kevin Clements, "Traditional, charismatic and grounded Legitimacy", Study for GTZ project "good governance and Democracy", www.oecd.org/dac/incaf/44794487.pdf, (2008).
} 
The subaltern has long been involved on transformative local and transnational scale projects, expressing an agency that confronted imperialism (and before it slavery, disenfranchisement, labour conditions, claimed a wide range of rights, opposed the arms trade and campaigned on cultural and environmental matters), and continues to push at the limits of progressive thought even today. ${ }^{39}$ Indeed, it is the localised aspect of peace formation, but particularly its social and emancipatory connections across history and geography that gives hybridity its purchase and empirical falsifiability in everyday contexts, along with an impact on the changing state and international peace architecture. It illustrates its 'contrapuntal' nature, to draw on Edward Said's work on hybridity (Said, 2004). ${ }^{40}$ The reality is that analogue and digital 'ungovernable-scapes'- localised or failed systems that are not under close to northern authority or global governance- continue to be self-governing in their own way, developing modes of peace formation. Peace formation does not seek to erase the international or the state, as it is cognizant of its very limited capacity, but it does try to reform them through subaltern means while making a space for a reformed polity to emerge. Peace formation communities consciously and unconsciously exercise critical agency aimed at designing a sustainable and emancipatory peace, reflecting local conditions and constraints, patterns of violence, structural and direct, and the possibilities imminent in the local and the international.

\section{Conclusion: Peace Formation and Heterotopia}

It is possible to be far more reflective about, aware of, and responsive to what Levinas has called, "[p]eace as awakeness to the precariousness of the other". ${ }^{41}$ Indeed, peace formation offers the

\footnotetext{
${ }^{39}$ See for example, Bill Ashcroft, Gareth Griffiths, Helen Tiffin, The Empire Writes Back: Theory and Practice in Post-Colonial Literatures, (London: Routledge 1989): Bill Ashcroft, PostColonial Transformation, (London: Routledge, 2001), p.2.

${ }^{40}$ Edward Said, Humanism and Democratic Criticism, (Columbia University Press, 2004).

${ }^{41}$ Emmanuel Levinas, "Peace and Proximity", AT Peperzak, S Critchley, and R Bernasconi (eds.), Basic Philosophical Writings, (Indiana University Press, 1984), p.167.
} 
possibility of transcending the inside-outside, bottom-up- top-down, us/other binaries that bedevil the praxes of peace, at least in discursive terms. However, power-relations cannot be wished away: they have to be addressed legitimately. Furthermore, it exposes the strategy of 'practicing' reforms on the post-conflict subjects before then transferring them elsewhere as a way of reinforcing the liberal states-system, and despites its internal contradictions. Peace formation is more focussed on the positive agencies expressed for peacemaking reflecting ' ...multiple degrees and sites of agency' and 'collective social assemblages'. ${ }^{42}$ Peace formation draws on anthropological and sociological insights on how well-being is conceived of in terms of the international, the state, social relations, kin networks, and an individual's position in them. These often point to the need for, or create 'moral economies' and redistributive networks in situations of overt and structural violence and poverty. ${ }^{43}$ It overturns structures of oppression, and often organises itself into hidden or public forms of resistance and mobilisation. It aims to redress inequality, to produce socio-historical legitimate institutions and practices, to learn from the international while reforming it, and to support positive hybrid forms of peace. Just as social movements and organisations across the world over the last century have engaged in a constant struggle with power hierarchies, as global civil society develops beyond the liberal, normative framings offered by Rawls, Habermas, and Kaldor, ${ }^{44}$ rights claims expand, and new networks and tools emerge. This points to a connection between the networked, mobile, and transversal qualities of peace formation, with new and perhaps "digital peace" dynamics.

Peace formation answers the question of who and what is peace for, and how might it be achieved? It offers clear (if the appropriate methods are applied) statements about what the causal factors of conflict are, and what local, state, and international measures are required, and how these may be broadly legitimate across scales. It also provides a basis through which the local may

\footnotetext{
${ }^{42}$ William E Connolly, A World of Becoming, (Duke University Press, 2011), p.22.

${ }^{43}$ David Booth, Melissa Leach, and Alison Tierney, "Experiencing Poverty in Africa: Perspectives from Anthropology", Background Paper $1 b$ for World Bank Poverty Status Report, (1999), p.10. \& p. 19
}

${ }^{44}$ Mary Kaldor, “The Idea of Global Civil Society”, International Affairs 79 (3) (2003): 583-593 
influence, negotiate with, and finally 'join' the international without co-optation or coercion. It offers navigation points for policies, as well as corrective influences on international architectures for peace. It offers the promise of a gradual and future alignment through mutual reform or through an acceptance of mediated difference.

Engaging with peace formation illustrates how power circulates and is exercised by the subaltern, requiring broad legitimacy even in the most obscure local forums holding it to account. Peace formation maintains the possibility of emancipation and empathy in a local to global framework. It draws on the values, identity and needs of its subjects, rather than solely on the 'benevolent' assumptions of national and global, Marxist, liberal, or neoliberal elites. It requires an understanding of 'habitus', of 'heterotopia', of 'self-formation', of the dense local to global, relational, mobile, digital networks of 'micro-solidarities', the possibilities of 'radical hybridity' across difference. ${ }^{45}$

Peace formation highlights the structural violence inherent in governmental power. However, it is clearly only a partial response to the vexed question of how to build peaceful local and global orders. It partially contradicts Eurocentric liberal norms, rights, and self-determination. Peace formation reflects the transversal circulation of power, but does not act as 'native enablers' of historical empires, ${ }^{46}$ liberal norms, or global capital. It maintains a high degree of autonomy, in identity, ideology, norms, and objectives. Peace formation struggles with structural power and governmentality but the agency it exercises is more than just that of bare life, protest, or compliance. Peoples, identities, cultures, needs, and rights, have been recognised across the world because of it. Direct, structural power and governmentality has been exposed and called to account through it, though it finds its limits in vested powerful interests at local, state, and global levels, and is only a partial response to the weak distribution of rights and material resources around the world.

Peace formation derives from those groups and communities who work for peace, actively

\footnotetext{
${ }^{45}$ Michel Foucault, "Of Other Spaces, Heterotopias" 1967, in Architecture /Mouvement/ Continuité, (October, 1984): trans. Jay Miskowiec.

${ }^{46}$ P Mishra, From the Ruins of Empire: The Revolt Against the West and the Remaking of Asia, (London: Penguin, 2012), p.60.
} 
and intellectually, in everyday and highly localised settings as well as within the institutions of the polity. They use history, identity, culture, religion, language, resources, boundaries, institutions, rights and needs, not as a means of division, but as a means through which bridges can be built by exercising subaltern power and critical agency and coaxing governmental and even direct or structural power to shift slightly in their favour. They understand the micro and meta-narratives of legitimacy, through which these relationships are rebuilt, and their historical sensitivities. They understand also how elites and political entrepreneurs abuse them or manipulate society. They understand how to mitigate such stresses. They have a heightened awareness of the multidimensional basis for peace, across time, space, societies, and the international system. They work slowly and quietly with minimal capacity.

The relationship that has emerged between power and peace formation indicates some important lessons. First, most power lies within direct, structural, and governmental systems that normally exercise top-down power on the subject. Subaltern actors may respond, but their response is very limited. Often the vertical top-down exercise of power has negative if unintended consequences upon the subaltern. Thus, the idea that subaltern power can be harmonised in unison with structural, direct, and governmental power, is probably a myth. It is likely that any peace framework that emerges from the interaction of peace formation with the state and international will be based upon managing difference and dealing with contradictions, rather than building a unified system.

Foregrounding peace formation, engaging with its signals, and understanding how peace is a political project- one among many- is a crucial next step in the development of an international architecture designed to improve international order rather than just to maintain it, especially in view of the need to reconsider the relationship between universalism and particularism that the tension between peace formation and the international peacebuilding architecture suggests. It is essential for substantive democratisation, human rights, understanding the role and nature of the state, as well as its legitimacy, and for the legitimacy of intervention to protect vulnerable subjects whilst also maintaining their political autonomy. Peace formation makes clearer the blockages to 
peace, who controls them, and how they operate (often with great subtlety).

Finally, foregrounding peace formation also helps to shed light on the growing shift from an analogue international system of citizens, states, and international architecture operating within the constraints of sovereignty, territory, human rights and institutions, to a digital system. In a digital peace framework, rights and justice claims are expanding across dense and far-reaching networks, at a pace never before seen. Distance has collapsed, citizenship is framed in non-territorial ways, and social legitimacy and responsibility is supplanting the state and the international, at least to a degree. Peace formation is clearly a little understood dynamic, but one which is influential in reshaping political order.

\section{Bibliography}

\section{Aggestam, K Annika Björkdahl Rethinking Peacebuilding}

The Quest for Just Peace in the Middle East and the Western Balkans London: Routledge

Agnew, J. (1987) Place and politics.( London: Allen and Unwin 2012).

Ashcroft, Bill, Gareth Griffiths, \& Helen Tiffin,. The Empire Writes Back: Theory and Practice in Post-Colonial Literatures, (London: Routledge 1989).

Ashcroft, Bill. Post-Colonial Transformation, (London: Routledge 2001).

Axtmann, Roland. “The State of the State”, International Political Science Review, Vol. 25, No. 3 (2004).

Beck, Ulrich, and Edgar Grande, Cosmopolitan Europe, (Cambridge: Polity, 2007).

Boege, Volker, Brown, Anne, Clements, Kevin and Nolan, Anna "On hybrid political orders and emerging states: What is failing - states in the global south or research and politics in the west?" Berghof Handbook Dialogue Series, 8 (2008): 15-35.

Boege, Volker "Legitimacy in hybrid political orders - an underestimated dimension of peacebuilding and state formation". Conference paper presented at the European Consortium of Political Research conference, Potsdam, Germany, 10 -12 September (2009). 
Booth, David, Melissa Leach, and Alison Tierney, "Experiencing Poverty in Africa: Perspectives from Anthropology”, Background Paper 1b for World Bank Poverty Status Report (1999).

Burton, John W. Conflict and Communication: The Use of Controlled Communication in International Relations. (London: Macmillan and New York: Free Press 1969).

Callinicos, A Against Post-modernism, (Polity: Cambridge 1989).

Chowdhury, Arjun, and Raymond Duvall "Sovereignty and Sovereign Power", International Theory, Vol. 6, No. 2. (2014).

Clements, Kevin "Traditional, charismatic and grounded Legitimacy", Study for GTZ project "good governance and Democracy", www.oecd.org/dac/incaf/44794487.pdf (2008)

Connolly, William E (2011). A World of Becoming, (Duke University Press, 2011).

Derrida, J "Force of Law", in D Cornell et all (eds.), Deconstruction and the Possibility of Justice, (London: Routledge 1992).

Diehl, Paul F. "Exploring Peace: Looking Beyond War and Negative Peace" International Studies Quarterly, 60 (1) (2016): 1-10

Escobar, A Territories of Difference: Place, Movements, Life, Rede, sDuke University Press Books (2008).

Foucault, M "Two Lectures," in Colin Gordon, ed., Power/Knowledge: Selected Interviews, (New York: Pantheon 1980).

Foucault, M “Of Other Spaces, Heterotopias" 1967, in Architecture /Mouvement/ Continuité, October: trans. Jay Miskowiec (1984). .

Foucault, M Society Must Be Defended, (New York: Picador 2003).

Galtung, J "Violence, Peace, and Peace Research" Journal of Peace Research, Volume: 6 issue: 3 (1969): 167-191

Habermas. J The Postnational Constellation: Political Essays, (Cambridge: MIT Press 2001).

Harvey, Neil The Chiapas Rebellion: The Struggle for Land and Democracy, (Duke University Press 1998).

Huntington, Samuel Political Order in Changing Societies, New Haven and London, Yale University Press (1968).

Jabri, V. War and the transformation of global politics (Basingstoke: Palgrave Macmillan 2010)

Johnson, Pat "Local vs National Peacebuilding: The Richness of Somali Peacemaking", www.prio.no/peaceethics/PeacE-Discussions. (2010) 
Kaldor, Mary “The Idea of Global Civil Society”, International Affairs 79 (3) (2003): 583-593

Lederach, John Paul Building Peace: Sustainable Reconciliation in Divided Societies, (Washington, DC: U.S. Institute of Peace Press 1997).

Levinas, Emmanuel "Peace and Proximity", AT Peperzak, S Critchley, and R Bernasconi (eds.), Basic Philosophical Writings, (Indiana University Press 1984).

Luckham, Robin, and Tom Kirk, "The Two Faces of Security in Hybrid Political Orders", Stability: International Journal of Stability and Development, Vol. 2, no. 2, (2013). pp.1-30.

Haiven, Max, and Alex Khasnabish The Radical Imagination, (London: Zed Books, 2014).

Marx, Karl The Eighteenth Brumaire of Louis Bonaparte [1869], (New York: International Publishers 1969).

Mishra, P From the Ruins of Empire: The Revolt Against the West and the Remaking of Asia, (London: Penguin 2012).

Mitchell, Timothy Rule of Experts, (Berkeley: University of California Press 2001).

Mitrany, D A Working Peace System: An Argument for the Functional Development of International Organization. (Oxford: Oxford University Press 1944)

Nadarajah, Suthaharan and Rampton, David 'The limits of hybridity and the crisis of liberal peace', Review of International Studies, Vol. 41, No.1, (2015) 49-72.

Nussbaum, Martha Creating capabilities: the human development approach. (Cambridge, Massachusetts: The Belknap Press of Harvard University Press 2011).

Odendaal, Andries A Crucial Link: Local Peace Committees and National Peacebuilding, (Washington DC: USIP. 2013).

Paris, R, At War's End: Building Peace After Civil Conflict (Cambridge: Cambridge University Press 2004).

Paras, Eric Foucault 2.0, (New York: Other Press 2006)

Qin, Yaqing. A Relational Theory of World Politics. International Studies Review Volume 18, Issue 1, 1 March (2016) 33-47

Rawls, John "The Law of Peoples," Critical Inquiry, Vol. 20, No. 1, (1993) pp. 36-68.

Regan, Patrick M. "Bringing peace back in: Presidential address to the Peace Science Society", Conflict Management and Peace Science, 31 (4) (2013): 345 - 356

Richmond Oliver P The Transformation of Peace, (London: Palgrave 2005). 
Richmond, Oliver P "Eirenism and a Post-Liberal Peace", Review of International Studies, Vol.35, No 3. (2009).

Richmond Oliver P A Post-Liberal Peace, (London: Routledge 2011)

Richmond, Oliver P Failed Statebuilding, (Yale University Press 2014).

Richmond, Oliver P "Dilemmas of a Hybrid Peace: Negative or positive?", Cooperation and Conflict, Vol. 50, No.1 (2015).

Richmond, Oliver P Peace Formation and Political Order, (Oxford: OUP 2016).

Said, Edward Humanism and Democratic Criticism,( Columbia University Press 2004).

Richard Shapcott "Global Justice: Shaped rather than Found", International Relations, firstview. (2017)

Solomon, Ty \& Brent J. Steele "Micro-moves in International Relations theory", European Journal of International Relations, Vol 23, Issue 2 (2017): 267 - 291

Tilly, Charles "War Making and State Making as Organized Crime". In Peter Evans; Dietrich Rueschemeyer; Theda Skocpol. Bringing the State Back In. Cambridge: Cambridge University Press. (1985) pp. 169-191. 